\title{
Long-term Cyclic Irrigation in Subsurface Drained Lands: Simulation Studies with SWAP
}

\author{
A.K. Verma ${ }^{1}$, S.K. Gupta ${ }^{2} \&$ R.K. Isaac ${ }^{3}$ \\ ${ }^{1}$ Scientist (Senior Scale), CIFE, Yari Road, Versova, Andheri (W), Mumbai, India \\ ${ }^{2}$ Emeritus Scientist, Central Soil Salinity Research Institute Karnal, India \\ ${ }^{3}$ Professor, Sam Higginbottom Institute of Agriculture, Technology \& Sciences (SHIATS), Allahabad, India \\ Correspondence: A.K. Verma, CIFE, Yari Road, Versova, Andheri (W), Mumbai, India. Tel: 91-222-631-0657. \\ E-mail: akverma45@yahoo.com
}

Received: October 24, 2012 Accepted: October 31, 2012 Online Published: December 13, 2012

doi:10.5539/jas.v5n1p84

URL: http://dx.doi.org/10.5539/jas.v5n1p84

\begin{abstract}
SWAP (Soil-Water-Atmosphere-Plant) version 2.0 was evaluated for its capability to simulate the crop growth and salinity profile for cyclic irrigation of saline waters at Sampla (India) having shallow water table provided with a subsurface drainage system. Cyclic mode with canal water $\left(\mathrm{EC}=0.4 \mathrm{dS} \mathrm{m}{ }^{-1}\right)$ and saline drainage water $\left(E C=12.5-15.5 \mathrm{dS} \mathrm{m}^{-1}\right)$ were used to calibrate and validate the model for the years 1989-91. Canal water was used for pre-sowing irrigation and thereafter, canal and saline drainage waters were used as per pre-decided irrigation modes like all $\mathrm{CW}, \mathrm{CW}: \mathrm{DW}, 2 \mathrm{CW}: 2 \mathrm{DW}, \mathrm{DW}: \mathrm{CW}$, and 1CW:3DW. Absolute deviations and standard error between the SWAP simulated and observed relative yields during calibration ranged from 1.3 to $1.8 \%$ and 1.7 to $2.2 \%$ respectively. A close agreement was observed between the measured and simulated soil salinity profile. It established the validity of SWAP model under the experimental conditions prevalent at the site. It could also be concluded that the crops could be grown very well under subsurface drainage conditions; but, in dry rainfall years, salinity build-up might occur. To achieve a yield potential exceeding $80 \%$, it could be suggested that cyclic use of saline waters such as $1 \mathrm{CW}: 1 \mathrm{DW}$ and $2 \mathrm{CW}: 2 \mathrm{DW}$ could be used in such years. A pre-sowing irrigation with canal water could be helpful to overcome the build-up of salts and salt amount washing depends upon the rainfall. Thus, there seems to be no fear of use of cyclic irrigation under drained conditions. The same fact was established through the use of model SWAP.
\end{abstract}

Keywords: simulation, SWAP, cyclic irrigation, relative yield, salinity profile

\section{Introduction}

Water logging and soil salinity is big problem in many arid and semi-arid regions, and a limited quantity of fresh water canal supply is limited. Subsurface drainage systems are commonly required for these irrigated lands to prevent waterlogging and to facilitate the leaching of salts from the crop root zone. However, subsurface drainage system produce saline drainage water, and disposal of such waters is a serious problem. With the increasing problems of disposal of saline drainage water under shallow water table condition and expanding demands on high quality water for other purposes, reuse of saline drainage water for irrigation has received considerable attention in this region (Sharma et al., 1989, 1991, 1993). Results of these studies and many other studies (Grattan et al., 1987; Rains et al., 1987; Rhoades et al., 1988a,b) have attested to the global potential of saline drainage water reuse for crop production. Saline drained waters can not be used directly, for this various strategies have been proposed (Rhoades, 1984; Boumans et al., 1988; Westcot, 1988; Sharma et al., 1991). Rhoades et al. (1989) and Bradford and Letey (1992) have mentioned the advantage of the cyclic over the blending strategy in most of the cases. In spite of the availability of such well conducted experimental data sets, due to location specificity of the problems, field experiments are still being conducted over the years. Even then the questions arise on the long-term applicability and sustainability of crop production with saline waters especially where groundwater is at shallow depth. Under such situations, simulation/computer models offer excellent support to explain the results, to reduce the required time and effort on repeat testing and simulate long-term consequences of the reuse of saline drainage waters (Workman \& Skaggs, 1989; Gupta et al., 1993; Breve et al., 1995; Breve et al., 1998). 
Although a number of models have been used to describe experimental data sets in the past, currently SWAP is being widely used due to its many distinctive features such as capability to simulate physical, chemical and biological processes at field scale and to accommodate long-term simulations with multiple crops per year. Besides, its capability to predict relative yield under varying water and salt regimes is quite attractive to the users since higher crop yield is the ultimate aim of any management option. Since the model has so far been tested on a very limited scale under monsoon climatic conditions as are prevalent in India, it was decided to test this model performance and applicability using available data on the use of saline water under shallow water table conditions. The objective of this paper has been to revisit the data on use of saline water, calibrate and validate the SWAP model and ascertain its performance to predict relative yield and salinity profiles under various management options to manage saline drainage effluents under shallow water table conditions in a semiarid monsoon climate.

\section{Brief Description of the SWAP Model}

SWAP is a deterministic model describing water, solute and heat transport in the saturated-unsaturated zone (van Dam et al., 1997). In this model soil water flow in the soil matrix in the unsaturated-saturated zone is described by the Richard's equation:

$$
\frac{\partial \theta}{\partial t}=C(h) \frac{\partial h}{\partial t}=\frac{\partial}{\partial z} K(h)\left[\left(\frac{\partial h}{\partial z}+1\right)-s(h)\right]
$$

Where, $\theta$ denotes the volumetric water content $\left(\mathrm{cm}^{3} \mathrm{~cm}^{-3}\right), \mathrm{t}$ the time (days), $\mathrm{C}$ the differential water capacity $\left(\mathrm{cm}^{-1}\right), \mathrm{h}$ the soil water pressure head $(\mathrm{cm}), \mathrm{z}$ the vertical coordinate positive in the upward direction $(\mathrm{cm}), \mathrm{K}$ the hydraulic conductivity $\left(\mathrm{cm} \mathrm{day}^{-1}\right)$ and $\mathrm{S}$ the soil water extraction rate by plant roots $\left(\mathrm{cm}^{3} \mathrm{~cm}^{-3} \mathrm{day}^{-1}\right)$.

SWAP consists of three different sub-models to simulate crop growth i.e. a) detailed crop growth, b) detailed grass growth and c) simple crop growth model. The simple crop growth model was used due to its simplicity and lack of observed data required to simulate with detailed crop growth model. In this model, the actual yield $\mathrm{Y}_{\mathrm{a}, \mathrm{k}}$ $\left(\mathrm{kg} \mathrm{ha}^{-1}\right)$ relative to the potential yield $\mathrm{Y}_{\mathrm{p}, \mathrm{k}}\left(\mathrm{kg} \mathrm{ha}^{-1}\right)$ for each development stage is calculated by:

$$
1-\left(\mathrm{Y}_{\mathrm{a}, \mathrm{k}} / \mathrm{Y}_{\mathrm{p}, \mathrm{k}}\right)=\mathrm{K}_{\mathrm{y}, \mathrm{k}}\left(1-\mathrm{T}_{\mathrm{a}, \mathrm{k}} / \mathrm{T}_{\mathrm{p}, \mathrm{k}}\right)
$$

Where $\mathrm{K}_{\mathrm{y}, \mathrm{k}}$ is the yield response factor of growing stage $\mathrm{k}$ and $\mathrm{T} \mathrm{p}, \mathrm{k}(\mathrm{cm})$ and Ta,k $(\mathrm{cm})$ are the potential and actual transpiration, respectively during growth stage $\mathrm{k}$. The relative yield of whole growing season is calculated as product of relative yield of each growing stage.

$$
\left(\mathrm{Y}_{\mathrm{a}} / \mathrm{Y}_{\mathrm{p}}\right)=\prod_{\mathrm{k}=1}^{\mathrm{n}}(\mathrm{Ya}, \mathrm{k} / \mathrm{Yp}, \mathrm{k})
$$

Where, $Y_{a}$ is the cumulative actual yield $\left(\mathrm{kg} \mathrm{ha}^{-1}\right)$ of whole growing season, $Y_{\mathrm{p}}$ is the cumulative potential yield $\left(\mathrm{kg} \mathrm{ha}^{-1}\right)$ of whole growing season, index $\mathrm{k}$ is the growing stage and $\mathrm{n}$ is the number of pre-defined growth stages.

In SWAP irrigation could be prescribed at fixed times or scheduled with a combination of irrigation prescriptions and scheduling criteria. The convection, dispersion and diffusion are the three main process of solute transport embedded in the SWAP model. The total solute flux is calculated according to equation:

$$
\mathrm{J}=\mathrm{qc}-\theta\left(D_{d i f}+D_{d i s}\right) \frac{\partial c}{\partial z}
$$

Where, $\mathrm{J}$ is the total solute flux density $\left(\mathrm{g} \mathrm{cm}^{-2} \mathrm{~d}^{-1}\right), D_{d i f}$ is the solute diffusion coefficient $\left(\mathrm{cm}^{2} \mathrm{~d}^{-1}\right), D_{d i s}$ is the solute dispersion coefficient $\left(\mathrm{cm}^{2} \mathrm{~d}^{-1}\right)$ and $\partial c / \partial z$ is the solute concentration gradient. The effect of salinity on crop yield is taken into account and is defined both by a critical EC level below which no salt stress occurs and by the decline of yield above the threshold EC given by the slope in percent crop yield reduction per unit

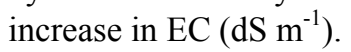

SWAP provides a wide range of upper and lower boundary conditions. Potential evapotranspiration, irrigation and precipitation describe upper boundary conditions of the system. The bottom boundary conditions can also be described through various options. Groundwater level as a function of time, flux to/ from semi confined aquifer, flux to/ from open surface drains, an exponential relationship between bottom flux and groundwater table or zero flux, free drainage or free outflow at the bottom of the profile. Measured groundwater levels as a function of time were considered to describe the bottom boundary condition.

The SWAP is user friendly with clear instructions on the operation of the model provided in the manual written by Kroes et al. (1999). 


\section{Materials and Methods}

The SWAP uses meteorological data such as daily rainfall, maximum and minimum temperature, wind velocity, relative humidity, sunshine hours and solar radiation on daily basis. Since most data except rainfall were not available for Sampla and moreover, climate conditions do not vary much, all the data sets were obtained from meteorological observatory at Karnal except the rainfall, which was obtained from the Sampla gauging station. The soil hydraulic properties and summary of the input data for crop and irrigation plans is reported in Table 1 and Table 2 respectively.

Table 1. Soil hydraulic properties parameters* for the experimental site

\begin{tabular}{lcc}
\hline Soil & Topsoil & Subsoil \\
\hline Depth of layer $(\mathrm{m})$ & $0-1.8$ & $1.8-3.0$ \\
Soil texture & Sandy loam & Sand/ loamy sand \\
Residual water content, $\theta_{\text {res }}\left(\mathrm{cm}^{3} \mathrm{~cm}^{-3}\right)$ & 0.02 & 0.01 \\
Saturated water content, $\theta_{\text {sat }}\left(\mathrm{cm}^{3} \mathrm{~cm}^{-3}\right)$ & 0.36 & 0.36 \\
Shape parameter, $\alpha\left(\mathrm{cm}^{-1}\right)$ & 0.017 & 0.021 \\
Shape parameter, $n$ & 1.45 & 2.0 \\
Shape parameter, $\lambda$ & 0.5 & 0.5 \\
Horizontal saturated hydraulic conductivity, $K_{x x}\left(\mathrm{~m} \mathrm{day}^{-1}\right)$ & 1.0 & 3.0 \\
Vertical saturated hydraulic conductivity, $K_{z z}\left(\mathrm{~m} \mathrm{day}^{-1}\right)$ & 0.25 & 0.75 \\
\hline
\end{tabular}

* Source: Hirekhan et al. (2007) and value selected from the proposed range suggested in the model SWAP

Table 2. Crop and irrigation data for the SWAP model for the study site

General

\begin{tabular}{|c|c|c|}
\hline Simulation period & \multicolumn{2}{|c|}{ 04/07/1984-30/06/2012 } \\
\hline Assumed crop rotation & \multicolumn{2}{|c|}{ Pearl millet-Wheat } \\
\hline Boesten parameter, $\beta_{\mathrm{p}}\left(\mathrm{cm}_{1 / 2}\right)$ & \multicolumn{2}{|c|}{0.54} \\
\hline Each irrigation water quantity (mm) & \multicolumn{2}{|c|}{100 (pre-irrigation); 70 (growing period) } \\
\hline$E C$ of irrigation water $\left(\mathrm{dS} \mathrm{m}^{-1}\right)$ & \multicolumn{2}{|c|}{0.4} \\
\hline Crop specific & Wheat & Pearl millet \\
\hline Length of crop cycle (days) & 145 & 79 \\
\hline Maximum crop height $(\mathrm{cm})$ & 90 & 150 \\
\hline Leaf Area Index, LAI (-) & $0.05-0.87-5.83-1.32$ & $0.05-0.50-6.00-3.00$ \\
\hline Maximum rooting depth $(\mathrm{cm})$ & 110 & 120 \\
\hline$h_{1}, h_{2}, h_{3 h}, \#$ & $-0.1,-1.0,-500$ & $-0.1,-1.0,-300$ \\
\hline$h_{3 l}, h_{4}(\mathrm{~cm}) \#$ & $-900,-16000$ & $-2500,-10000$ \\
\hline Threshold $E C_{e}\left(\mathrm{dS} \mathrm{m}^{-1}\right)$ & 4.0 & 6.8 \\
\hline Slope $\left(\%\right.$ per $\left.\mathrm{dS} \mathrm{m}^{-1}\right)$ & 3.5 & 16.0 \\
\hline Minimum canopy resistance $\left(\mathrm{S} \mathrm{m}^{-1}\right)$ & 0.70 & 0.70 \\
\hline Precipitation interception coefficient & 0.25 & 0.25 \\
\hline
\end{tabular}

\#Parameters of Feddes functions for simulating the effect of matric stress on plant growth (Adjusted as per values suggested by Wesseling et al. (1991) and Taylor and Ashcroft (1972)

Maximum crop height, Leaf Area Index (LAI), and maximum rooting depth are given as a function of the crop development stage. The LAI values for each crop relate to the start of the initial stage (emergence), the end of the initial stage, the mid-season stage and the end of the season stage, respectively. Basal crop factors that relate only to crop transpiration and not to soil evaporation (soil evaporation is treated separately by SWAP; van Dam et al., 1997) were used. Solute transport parameters required for simulation of salt transport are summarized in 
Table 3 while the relevant parameters of drainage system are reported in Table 4 . In the present study, the recorded data for the years 1989-1991 were used to calibrate and validate model. Since the model output is in the form of relative yields as a fraction of the optimum yield, the observed relative yields were calculated by dividing the yield of wheat with cyclic mode of irrigation (treatments $\mathrm{CW}: \mathrm{DW}, 2 \mathrm{CW}: 2 \mathrm{DW}, \mathrm{DW}: \mathrm{CW}$, and $1 \mathrm{CW}: 3 \mathrm{DW}$ ) to the yield of wheat irrigated with canal water (treatment $\mathrm{CW}$ ), which was assumed as the optimum yield. The data for the drain spacing of $50 \mathrm{~m}$ alone were used as it represents the current $60-67 \mathrm{~m}$ spacing being adopted in the state of Haryana.

Table 3. Parameters of solute transport** used to calibrate and validate the model

Sampla

Initial soil $E C_{e}\left(\mathrm{dS} \mathrm{m}^{-1}\right)$

Initial $E C$ groundwater $\left(\mathrm{dS} \mathrm{m}^{-1}\right)$

Dispersion length, $\alpha_{\mathrm{L}}(\mathrm{cm})$

Diffusion coefficient in water, $D_{w}\left(\mathrm{~cm}^{2} \mathrm{~d}^{-1}\right)$
52.2 at soil surface

18.1 at $18 \mathrm{~cm}$ depth and below

27.0

10.0

0.72

**Source: Adjusted within the range suggested by SWAP

Table 4. Parameters describing the drainage system

\begin{tabular}{lc}
\hline Drainage system & Sampla \\
\hline Drain diameter (m) & 0.1 \\
Drain depth (m) & 1.75 \\
Drain spacing (m) & $25,50,75$ \\
Depth to impermeable layer (m) & 3 \\
Include canal seepage (mmday $\left.{ }^{-1}\right)$ & 0 \\
Include tube well extraction $\left(\mathrm{mm} \mathrm{day}^{-1}\right)$ & 0 \\
\hline
\end{tabular}

\subsection{Model Performance Evaluation}

The performance of the model was statistically evaluated by comparing the measured relative yield with the simulated results. The agreement between the measured and predicted values was statistically quantified by calculating the standard error and absolute deviation. Statistically, the average absolute deviation and standard error are indicators of quantitative dispersion between the measured and predicted values. The standard error was calculated as:

$$
\text { Standard Error }(S E)=\sqrt{\frac{\sum(Y m-Y p)^{2}}{\mathrm{n}}}
$$

Where, $\mathrm{SE}$ is the standard error, $\mathrm{n}$ is the number of observations considered in the test, $\mathrm{Ym}$ is the measured values and $\mathrm{Yp}$ is the predicted value.

The average absolute deviation (AD) was computed for each test period as follows:

$$
\text { Absolute Deviation }(A D)=\frac{\Sigma|Y m-Y p|}{n}
$$

The variables in this equation have the same meaning as for SE (Equation 5). 


\section{Results and Discussion}

\subsection{Calibration}

The cyclic modes of conjunctive use of fresh and saline water experiments at the site began in 1989-90 to reuse saline water. The data of the first year were used to calibrate the model. The simulated results were in close agreement with the observed values (Figure 1). From these results, it could be concluded that the calibration parameters used in the model simulate well. The values of average absolute deviations and standard error for relative yield were $1.3 \%$ and $1.7 \%$ for the year $1989-90$. These values of AD and SE for relative yield are within the acceptable range as reported by Wahba et al. (2002), and Verma et al. (2010).

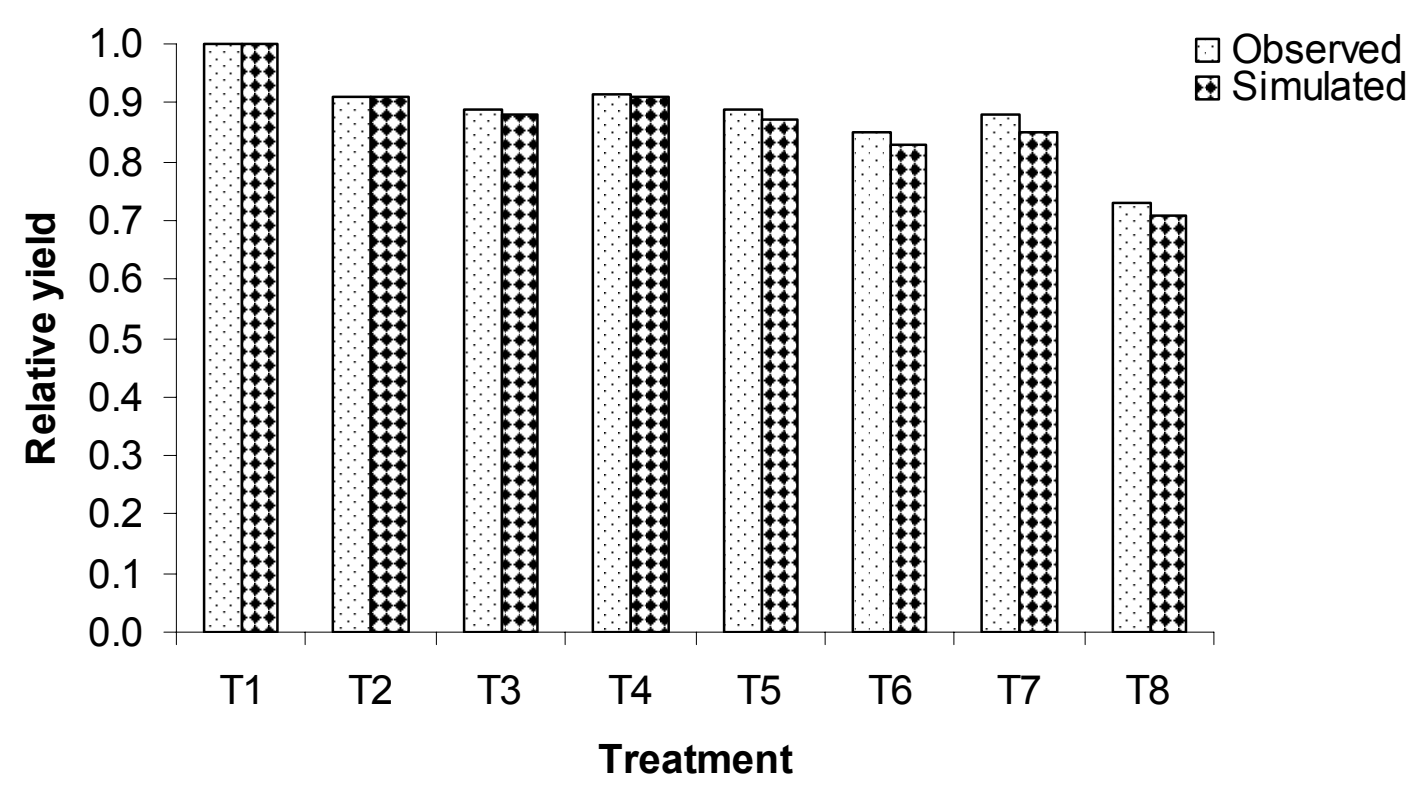

Figure 1. Comparison of measured and simulated relative crop yield during 1989-90 (calibration)

The data of salinity profiles for the same years as used in crop yield calibration were used to calibrate the model for the Sampla site. The results showed that the model simulations captured the trend of the salinity profile well (Figure 2).

The deviations observed at various points and times could be attributed to the following factors:

1). Under the field conditions, a large spatial variability in the values of soil parameters have been reported (Sharma et al., 2003).

2). Pumping of drainage water was suspended temporarily at times to enhance the contribution of groundwater to meet a part of the crop water requirements (Rao et al., 1992).

3). Cropping was initiated in the 1984-85. In the first few years, wheat, barley and sorghum were grown in winter, while pearl millet, sorghum and cotton were grown in the summer season. Simulations in this study have been made only for the crop rotation of pearl millet and wheat for which sufficient data for the use of model were available.

4). Water balance studies indicate that the contribution of seepage from the surrounding area could be up to $20 \%$ during the monsoon season (Rao et al., 1996). However, this contribution was not considered in these simulations. There is a possibility to consider such contributions while using model SWAP. 


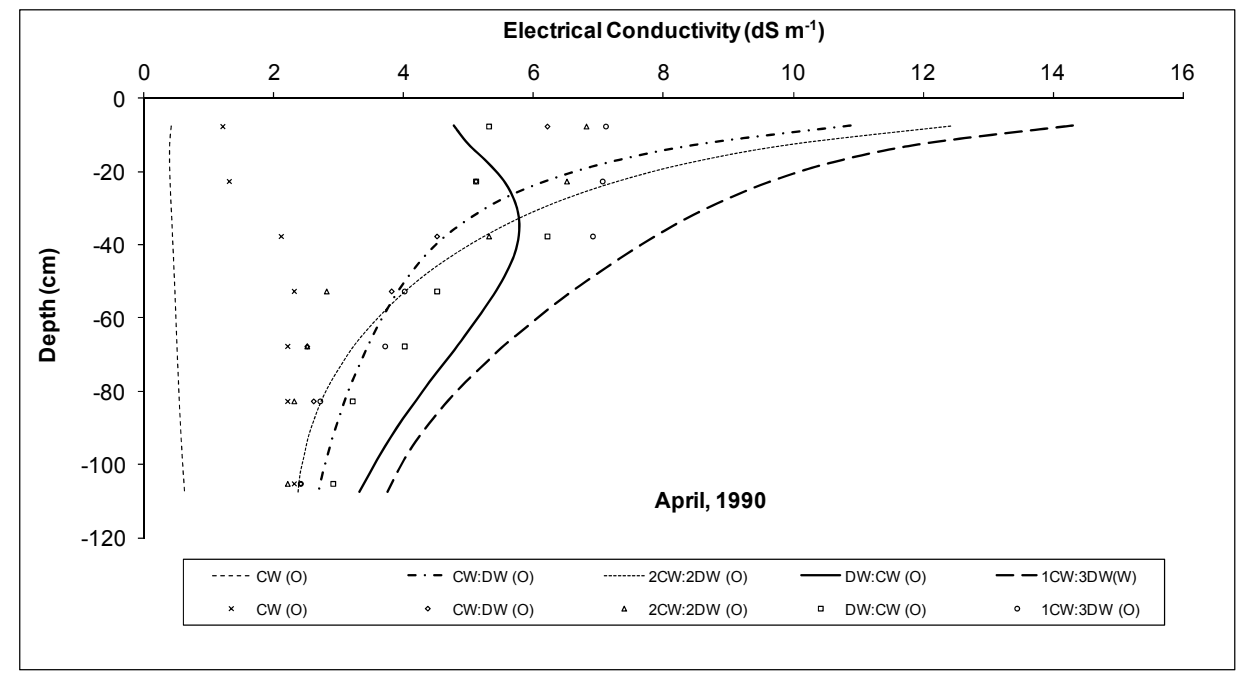

Figure 2. Measured (O) and simulated (S) salinity profiles with different cyclic treatments at harvest of wheat crop

On the basis of the results presented in Figure 2, it seems that the performance of the model is quite excellent at higher salinity levels and goes down to good and poor with decreasing salinity levels. It could be attributed to the terms such as dispersion length and molecular diffusion coefficient, which needed to be taken as variables rather than as constants as was done in these simulations. Similar results in other models were obtained when the term leaching efficiency was used as a constant than as a variable (Gupta, 2002).

From the results obtained for various simulations, it could be concluded that in spite of little deviations at some points an excellent visual match could be obtained between the observed and the simulated values. The deviation between predicted and measured data revealed that $\mathrm{AD}$ was $1.35 \mathrm{dS} / \mathrm{m}$ and $\mathrm{SE}$ was $1.58 \mathrm{dS} / \mathrm{m}$ for salinity profile which are on the lower side of the range reported by Hirekhan et al. (2007) for this parameter using model WaSim.

\subsection{Validation}

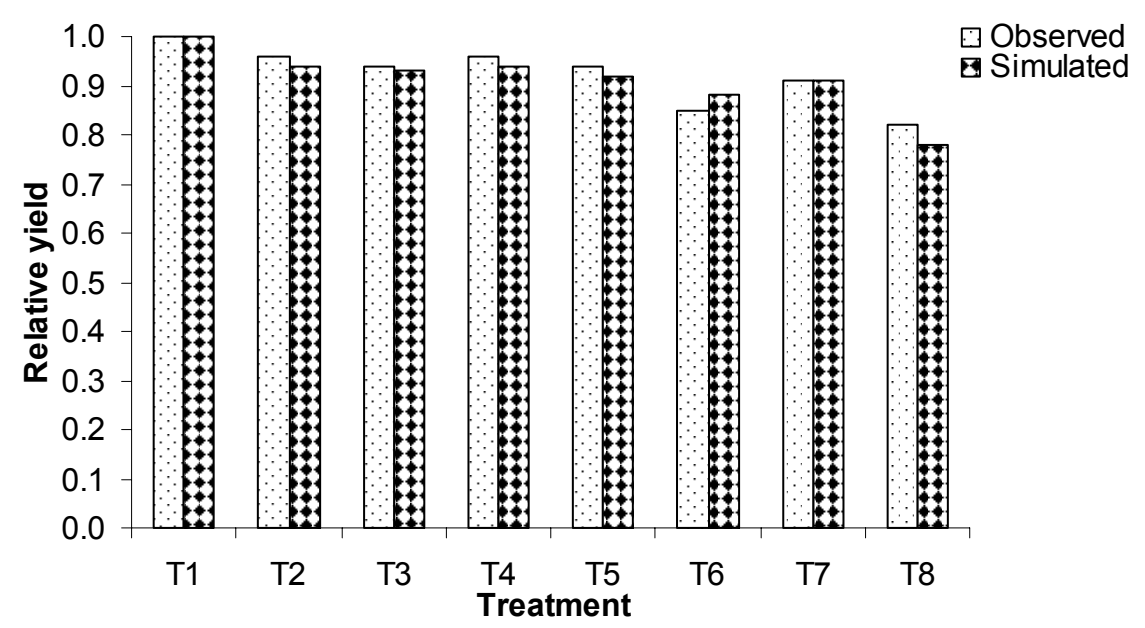

Figure 3. Comparison of measured and simulated relative yield (1990-91)

During the validation period (1990-91), parameters finalized during calibration were used. The simulated and the observed data on relative crop yield shown in Figure 3 revealed an excellent match between the observed and the predicted values at all salinity levels and cyclic modes. The values of average absolute deviations and standard 
error for relative yield ranged from $1.8 \%$ and $2.2 \%$ respectively. Comparing the results obtained with the study obtained by Wahba et al. (2002), it seems that the present simulation has yielded an excellent agreement between simulated and observed results.

The validated and the observed salinity profile shown in Figure 4 reveal a good match between the observed and predicted salinity profiles. The discussions and comments made during the calibration of this parameter hold true for the results obtained during validation as well. The values of AD $(1.12 \mathrm{dS} / \mathrm{m})$ and SE (1.54 $\mathrm{dS} / \mathrm{m})$ for salinity profile are even much lower side of range reported by Hirekhan et al. (2007).

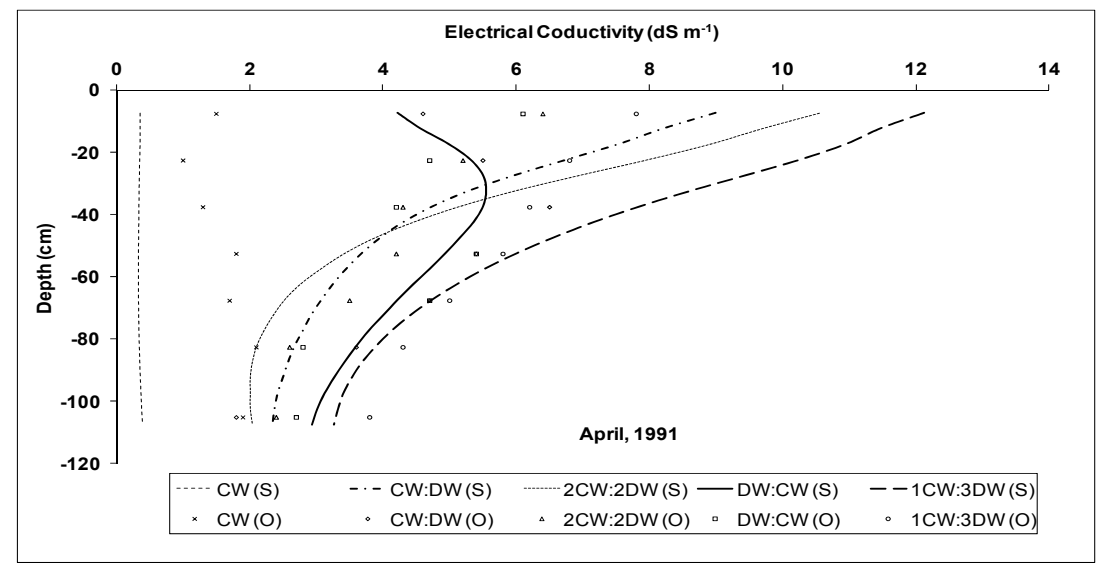

Figure 4. Measured (O) and simulated (S) salinity profiles at crop harvest with different cyclic treatments

\subsection{Scenario Building to Assess the Management Options for the Shallow Water Table}

The benefits of a modeling exercise truly emerge when the model is used for scenario-building exercises so that performance of various interventions or management options could be assessed through their impact on the problems of the area and/or on land and water resources once a given option is implemented. SWAP in prediction mode requires similar data sets as are needed during its calibration and validation.

\subsubsection{Relative Crop Yield under no Drainage Situation}

Sometimes, question arises whether a costly intervention like subsurface drainage is at all required to sustain the reclamation process particularly in situations where the farmers are unwilling to operate the system through pumped outlets. To respond to this query, a scenario was constructed where crop yields for various treatments were predicted with drainage as well as under the assumption that the drainage system is closed after the reclamation (no drainage situation). The maximum relative crop yield was only $40 \%$ in no drainage case with canal water compared to $100 \%$ with drainage (Figure 5). The yield further reduced to $17 \%$ of the optimum yield when all drainage water was used to irrigate the crops in no drainage case. Contrarily, as much as $78 \%$ of the yield could be obtained under land drainage. Similar improvement in yield was observed under other treatments as well. Clearly, the yields were affected due to excess water and soil salinity stresses under non-drained conditions. Salinity stress did affect the yield even under drained conditions, but to a much lesser extent. This exercise clearly established the fact that a subsurface drainage system is essentially required not only to reclaim the land but also to sustain optimum yields by maintaining the salt balance when saline water is used to grow crops.

\subsubsection{Relative Crop Yield under Drained Situation}

To see the sustainability of land reclamation, the wheat crop yield in a pearl millet-wheat rotation were predicted during years 2000-2012 under drained situation. Since the pearl millet crop was taken as rain fed, treatments could be tested only for the wheat crop. Long-term scenario building exercises over a period of thirteen years revealed that the crop yield varied from 77 to $95 \%, 75$ to $94 \%, 77$ to $94 \%$, and 69 to $88 \%$ with different cyclic use strategies such as 1CW:1DW, 1DW:1CW, 2CW:2DW, and 1CW:3DW respectively (Table 5). Clearly, over the simulation period of 13 years, the yield range $(77-95 \%)$ in treatments $1 \mathrm{CW}: 1 \mathrm{DW}, 1 \mathrm{DW}: 1 \mathrm{CW}$ and $2 \mathrm{CW}: 2 \mathrm{DW}$ could be better option for wheat production in areas with fresh water scarcity. It showed that reclamation of waterlogged saline lands is sustainable in the long run. Indirectly, it is also justified to say that there is not much build-up of salts on annual basis in the profile. 


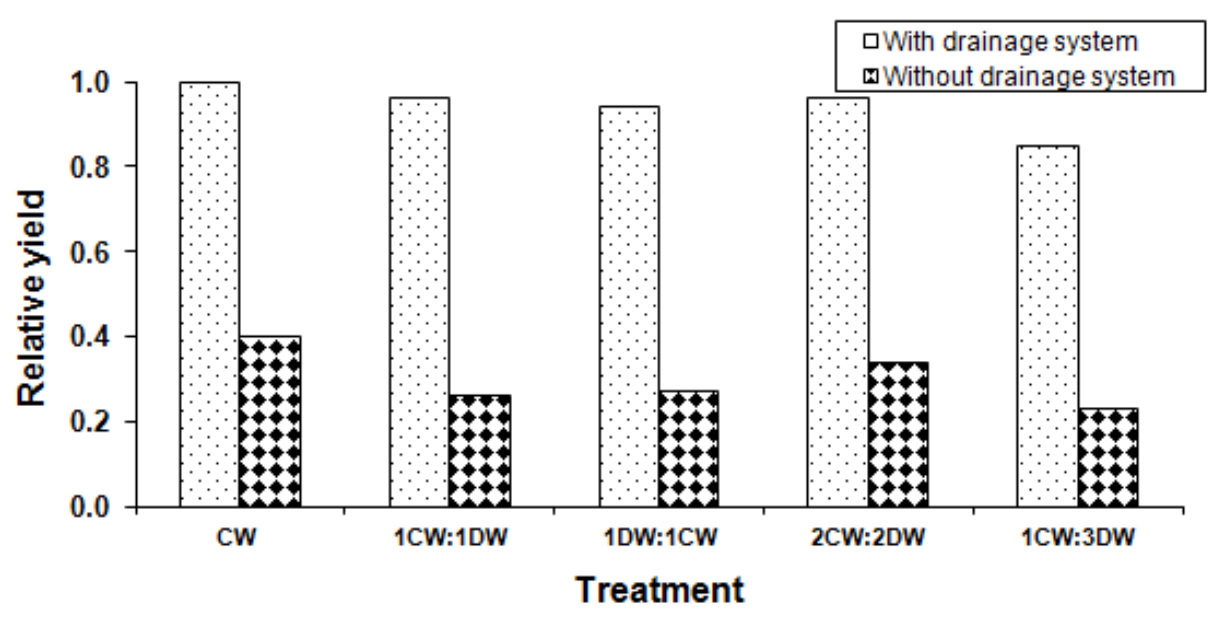

Figure 5. Comparison of relative yields (1990-1991) with and without subsurface drainage system

Table 5. Relative yields with different cyclic mode for different years.

\begin{tabular}{ccccccc}
\hline \multirow{2}{*}{ S.No. } & Year & \multicolumn{5}{c}{ Different modes } \\
\cline { 3 - 6 } & & CW & 1CW:1DW & 1DW:1CW & 2CW:2DW & 1CW:3DW \\
\hline 1. & 2000 & 1.00 & 0.95 & 0.93 & 0.94 & 0.88 \\
2. & 2001 & 1.00 & 0.95 & 0.94 & 0.94 & 0.88 \\
3. & 2002 & 1.00 & 0.94 & 0.93 & 0.93 & 0.86 \\
4. & 2003 & 1.00 & 0.94 & 0.91 & 0.94 & 0.86 \\
5. & 2004 & 1.00 & 0.94 & 0.93 & 0.94 & 0.87 \\
6. & 2005 & 1.00 & 0.93 & 0.91 & 0.93 & 0.85 \\
7. & 2006 & 1.00 & 0.91 & 0.87 & 0.91 & 0.84 \\
8. & 2007 & 1.00 & 0.94 & 0.93 & 0.93 & 0.86 \\
9. & 2008 & 1.00 & 0.83 & 0.79 & 0.82 & 0.73 \\
10. & 2009 & 1.00 & 0.86 & 0.85 & 0.87 & 0.77 \\
11. & 2010 & 0.99 & 0.77 & 0.75 & 0.77 & 0.69 \\
12. & 2011 & 1.00 & 0.87 & 0.85 & 0.87 & 0.80 \\
13 & 2012 & 1.00 & 0.89 & 0.87 & 0.88 & 0.81 \\
\hline
\end{tabular}

\subsubsection{Annual and Long-term Salinity Build-up}

Long-term use of saline water even in cyclic mode has been commented upon adversely because of the fear of salt build-up in the long-term. Since experiments are usually conducted over a few years, it has been difficult to remove this fear. Many modelers have discounted such a build-up (Sarwar \& Bastiaanssen, 2001; Sarwar et al., 2001; Tedeschi \& Menenti, 2002; Singh, 2004; Verma et al., 2010). To understand the process of salt build-up and leaching as influenced by the irrigation water salinity and rainfall during the monsoon season weekly solute concentrations were predicted during years 2000-2012 with different cyclic mode of irrigation water. The soil salinity in $0-15 \mathrm{~cm}$ soil profile at the beginning of November (before sowing of wheat, Figure 6) and mid of April (at the time of wheat harvest, Figure 7) revealed that the salinity before sowing of wheat was quite high in few years. But, the redeeming feature is that there is no long-term salinity build-up in the root zone. For example, salinity build-up during 2005, 2007 and 2009 gets washed away in 2006, 2008 and 2010. Long-term simulations also attests to the conclusion drawn from the annual salinity build-up scenario that in dry years it would be necessary to apply a heavy pre-sowing irrigation to leach down the salts before sowing of wheat crop. On the other hand, in the long-term one may not worry much about the development of soil salinity in the presence of a drainage system. 


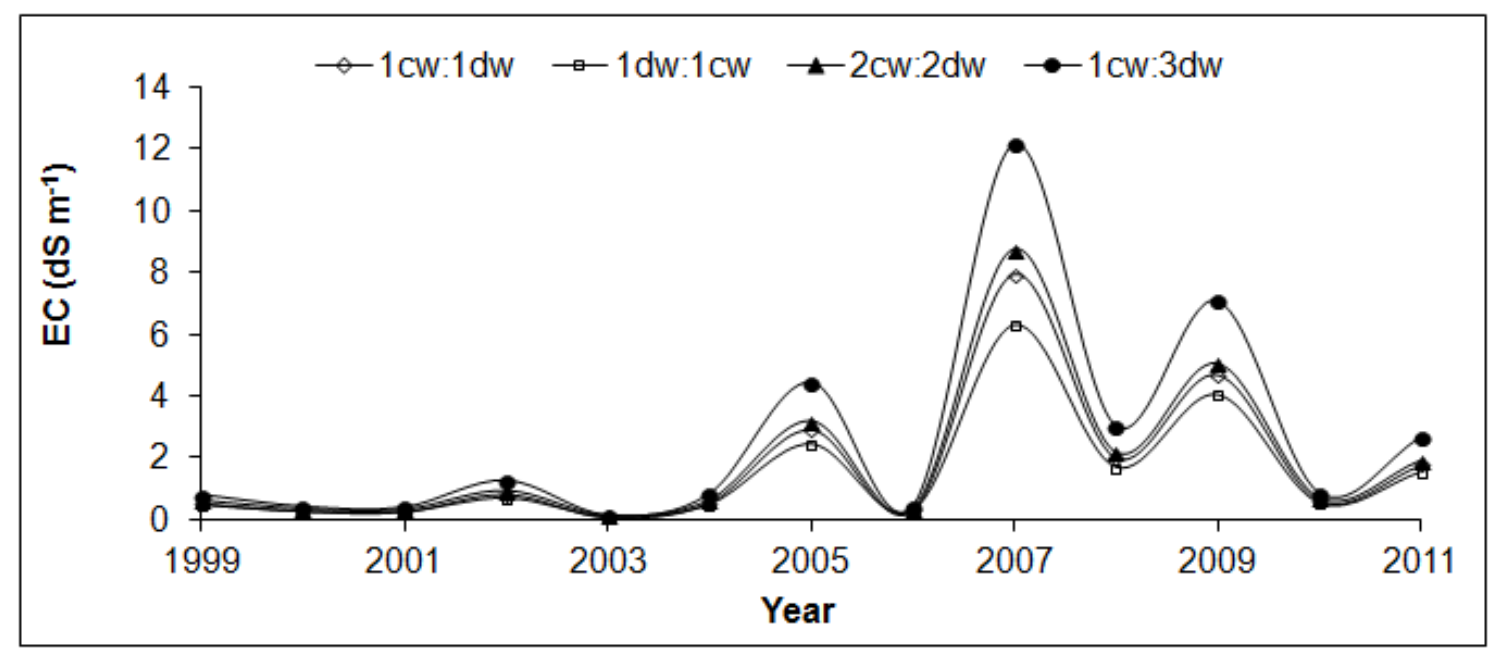

Figure 6. Annual salinity build-up with cyclic mode (before sowing of wheat)

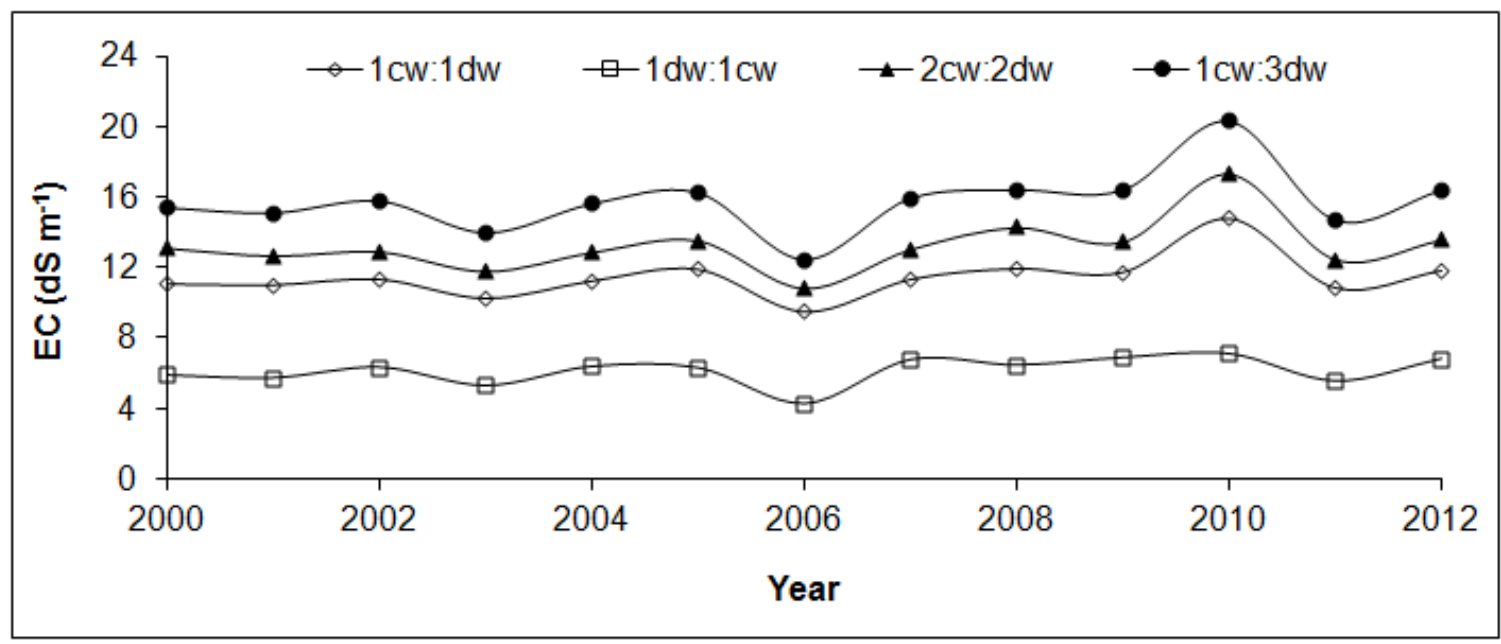

Figure 7. Annual salinity build-up with cyclic mode (at the time of wheat harvest)

\section{Conclusions}

From this study, following conclusions could be drawn.

It would difficult to reclaim the land without the intervention of a drainage system. Therefore, subsurface drainage system is very much required for such situations where shallow ground water table prevails through out the year.

The crops could be grown very well under subsurface drainage conditions but in dry rainfall years, salinity build-up might occur. To achieve a yield potential exceeding $80 \%$ it could be suggested that saline waters with cyclic use for conjunctive mode such as $1 \mathrm{CW}: 1 \mathrm{DW}$ and $2 \mathrm{CW}: 2 \mathrm{DW}$ could be used in such years. A pre-sowing irrigation with canal water could be helpful to overcome the build-up of salts.

Since the simulated results matched well the observed results at Sampla, SWAP model seems to be a useful tool to assess the performance of subsurface drainage system with use of cyclic use of saline waters for irrigations.

\section{References}

Boumans, J. H., Van Hoorn, J. W., Kruseman, G. P., \& Tanwar, B. S. (1988). Water table control, reuse and disposal of drainage water in Haryana. Agricultural Water Management, 14, 537-545. http://dx.doi.org/10.1016/0378-3774(88)90103-5

Bradford, S., \& Letey, J. (1992). Cyclic and blending strategies for using non-saline and saline waters for irrigation. Irrigation Science, 13, 123-128. http://dx.doi.org/10.1007/BF00191054 
Breve, M. A., Skaggs, R. W., Passons, J. E., \& Gilliam, J. W. (1998). Using the DRAINMOD- N model to study effects of drainage system design and management on crop productivity, profitability and $\mathrm{NO}_{3}-\mathrm{N}$ losses in $\begin{array}{lllll}\text { drainage } & \text { water. } & \text { Agricultural } & \text { 227-243. }\end{array}$ http://dx.doi.org/10.1016/S0378-3774(97)00035-8

Breve, M. A., Skaggs, R. W., Passons, J. E., Mohammad, A. T., \& Gilliam, J. M. (1995). Simulation of drainage water quality with DRAINMOD. Irrigation and Drainage System, 9, 259-277. http://dx.doi.org/10.1007/BF00880867

Grattan, S. R., Shennan, C., May, D. W., Mitchell, J. P., \& Bureau, R. G. (1987). Use of drainage water for irrigation of melons and tomatoes. California Agriculture, 41, 27-28. http://californiaagriculture.ucanr.org/landingpage.cfm?articleid=ca.v041n09p27

Gupta, G. P., Prasher, S. O., Chieng, S. T., \& Mathur, I. N. (1993). Application of DRAINMOD under semi-arid conditions. Agricultural Water Management, 24, 63-80. http://dx.doi.org/10.1016/0378-3774(93)90062-F

Gupta, S. K. (2002). Future prospect of subsurface drainage in India. Journal of Water Management, 10, 49-57.

Hirekhan, M., Gupta, S. K., \& Mishra, K. L. (2007). Application of WaSim to assess performance of a subsurface drainage system under semi-arid monsoon climate. Agricultural Water Management, 88, 224-234. http://dx.doi.org/10.1016/j.agwat.2006.12.001

Kroes, J. G., van Dam, J. C., Huygen, J., \& Vervoort, R. W. (1999). User's Guide of SWAP version 2.0; simulation of water flow, solute transport and plant growth in the Soil-Water-Atmosphere-Plant environment. Wageningen Agricultural University. Report 81, DLO Winand Staring Centre. Technical Document, 53, 128. Retrieved from http://edepot.wur.nl/222773

Rains, D. W., Goyal, S., Weyranch, R., \& Lauchli, A. (1987). Saline drainage water reuse in a cotton rotation system. California Agriculture, 41, 24-26. Retrieved from http://californiaagriculture.ucanr.org/landingpage.cfm?articleid=ca.v041n09p24

Rao, K. V. G. K., Sarma, D. P., \& Oosterbaan, R. J. (1992). Subirrigation by ground water management with controlled subsurface drainage in semiarid areas. In Proceeding of International Conference on supplementary irrigation and drought water management (p. 9), 1992, Bari.

Rao, K. V. G. K., Sharma, D. P., Kumbhare, P. S., \& Oosterbaan, R. J. (1996). Impact of subsurface drainage on salt regime of root zone and groundwater. In Proceeding of $6^{\text {th }}$ Drainage Workshop (pp. 657-663), ICID, 1996, Ljubljana.

Rhoades, J. D. (1984). Use of saline water for irrigation. California Agriculture, 38(10), 42-43. Retrieved from http://californiaagriculture.ucanr.org/landingpage.cfm?articleid=ca.v038n10p42

Rhoades, J. D., Bingham, F. T., Letey, J., Dedrick, A. R., Bean, M., Hoffman, G. J., ... Lemert, R. D. (1988a). Reuse of drainage water for irrigation: results of Imperial valley study. 1. Hypothesis, experimental procedures and cropping results. Hilgardia, 56, 1-16. http://dx.doi.org/10.1016/0378-3774(89)90038-3

Rhoades, J. D., Bingham, F. T., Letey, J., Hoffman, G. J., Pinter, P. J. Jr., \& Replogle, J. A. (1989). Reuse of drainage water for irrigation: Imperial valley study. Agricultural Water Management, 16, 25-26. Retrieved from http://www.sciencedirect.com/science/article/pii/0378377489900383

Rhoades, J. D., Bingham, F. T., Letey, J., Pinter, P. J. Jr., Lemert, R. D., Alves W. J., .. Pachcco, P. G. (1988b). Reuse of drainage water for irrigation: results of Imperial valley 2. Hypothesis, experimental procedures $\begin{array}{lllll}\text { and } \quad \text { cropping } & \text { results. } & \text { Hilgardia, } & 56, & 17-44 .\end{array}$ http://agris.fao.org/agris-search/search/display.do?f=1989/US/US89120.xml;US8931806

Sarwar, A., \& Bastiaanssen, W. G. M. (2001). Long-Term Effects of Irrigation Water Conservation on Crop Production and Environment in Semiarid Areas. Journal of Irrigation and Drainage Engineering, 127(6), 331-338. http://dx.doi.org/10.1061/(ASCE)0733-9437(2001)127:6(331)

Sarwar, A., Bastiaanssen, W. G. M., \& Feddes, R. A. (2001). Irrigation water distribution and long-term effects on crop and environment. Agricultural Water Management, 50, 125-140. http://dx.doi.org/10.1016/S0378-3774(01)00094-4

Sharma, D. P., Singh, K. N., \& Rao, K. V. G. K. (1989). Reuse of saline drainage water for irrigation of wheat. Indian Farming, 39, 32-33. http://dx.doi.org/10.1016/0378-3774(91)90043-I 
Sharma, D. P., Singh, K. N., Rao, K. V. G. K., \& Kumbhare, P. S. (1991). Irrigation of wheat with saline drainage water on a sandy loam soil. Agricultural Water Management, 19, 223-233. Retrieved from http://www.sciencedirect.com/science/journal/03783774/19/3

Sharma, D. P., Singh, K. N., Rao, K. V. G. K., \& Kumbhare, P. S. (1993). Management of subsurface saline drainage water. Indian Farming, 43, 15-19. Retrieved from http://link.springer.com/article/10.1007\%2FBF00187792

Sharma, K. K., Gupta, S. K., Singh, R. P., \& Chauhan, H. S. (2003). Comparison of conventional and geostatistical procedures for assessing hydraulic conductivity for drainage design. J. of the Indian Society of Soil Science, 51, 489-495. Retrieved from http://www.indianjournals.com/ijor.aspx?target $=$ ijor:jisss \& volume $=51 \&$ issue $=4 \&$ article $=016$

Singh, R. (2004). Simulations on direct and cyclic use of saline waters for sustaining cotton-wheat in a semi-arid area of north-west India. Agricultural Water Management, 66, 153-162. http://dx.doi.org/10.1016/j.agwat.2003.10.007

Taylor, S. A., \& Ashcroft, G. M. (1972). Physical Edophology. In W. H. Freeman \& Co. San Francisco (Eds.) (pp. 434-435).

Tedeschi, A., \& Menenti, M. (2002). Simulation studies of long-term saline water use: model validation and evaluation of schedules. Agricultural Water Management, 54, 123-157. http://dx.doi.org/10.1016/S0378-3774(01)00140-8

van Dam, J. C., Huygen, J., Wesseling, J. G., Feddes, R. A., Kobat, P. E. V., van Waslsum, Groenendijk, P., \& Diepen, C. A. (1997). Theory of SWAP version 2.0. Department of Water Resour., Report 71, Wageningen Agricultural University, Wageningen, The Netherlands (p. 167). Retrieved from http://www.swap.alterra.nl/DownloadHistory/swap207d/Swap207d theory (TechDoc 45).pdf

Verma, A. K., Gupta, S. K., \& Isaac, R. K. (2010). Long-term Use of Saline Drainage Waters for Irrigation in Subsurface Drained Lands: Simulation Modelling with SWAP. Journal of Agricultural Engineering, 47, 15-23. Retrieved from http://epubs.icar.org.in/ejournal/index.php/JAE/article/view/14619

Wahba, M. A. S., Ganainy, M. E., Dayem, M. S. A., Kandil, H., \& Gobran, A. (2002). Evaluation of DRAINMOD-S for simulating water table management under semi-arid condition. ICID Journal, 51(3), 213-226. http://onlinelibrary.wiley.com/doi/10.1002/ird.54/pdf

Wesseling, J. G., Elbers, J. A., Kabat, P., \& van den Broek, B. J. (1991). SWATRE: instructions for input. Internal note, Winand Staring Center, Wageningen, The Netherlands. International Waterlogging and Salinity Research Institute (p. 29), Lahore, Pakistan.

Westcot, D. W. (1988). Reuse and disposal of higher salinity subsurface drainage water-a review. Agricultural Water Management, 14(1-4), 483-511. http://dx.doi.org/10.1016/0378-3774(88)90100-X

Workman, S. R., \& Skaggs, R. W. (1989). Comparison of two drainage simulation models using field data. Transactions of the ASAE, 32(6), 1933-1938. Retrieved from http://elibrary.asabe.org/abstract.asp?aid=31245\&t=2\&redir=\&redirType= 